\title{
Investigating IQ, EQ and SQ Components of Malay Muslim Moral Structure in the Course of Psychological Dilemma
}

\author{
Aswati Hamzah ${ }^{1}$, Mohd Zailani Mohd Yusoff ${ }^{2}$, Nordin Abd Razak ${ }^{1}$ \\ ${ }^{1}$ Universiti Sains Malaysia, ${ }^{2}$ Universiti Utara Malaysia, Malaysia
}

\begin{abstract}
Moral structure represents one's accumulative knowledge, experiences and moral feeling on the search of moral meaning throughout their life. In the field of moral psychology, psychological dilemma was repeatedly use as a device to assess and to engage individuals in moral discourse. This article focused on the study exploring the Intelligent Quotient (IQ), Emotional Quotient (EQ) and Spiritual Quotient (SQ) components embedded on the Malay Muslim moral structure presented in a series of moral dilemma. Data was taken from cognitive psychology points of view via an assessment processes employing quantitative and qualitative approaches to investigate the appropriateness of the dilemma presented, and the representation of the moral elements embedded in each dilemma penetrating Malay cultural context, believe system, tradition as well as religious value.

The overall result of the study is highlighted, with great emphasis given to the strengths and weaknesses of employing hypothetical event on assessing students' moral reasoning as well as describing the process involving the integration of $I Q, E Q$ and SQ components in the search of moral meaning in one's life. Hence, this leads us towards implementing psychological dilemma from the moral cognition perspective to benefit pedagogical practices in promoting moral development of the Malay Muslim students.
\end{abstract}

\section{Introduction}

Being one of the main niche studies of psychological dilemma, hypothetical dilemma is used to a large extent in the field of moral reasoning to investigate cognitive process related to individual's moral structure in specific and moral development as a whole. This approach receives positive response as well as criticisms from various perspectives over the decades. Most of the denunciations root from the inconsistent predictions of one's moral reasoning ability assessed by hypothetical dilemma and failure to act simultaneously while dealing with real life moral dilemma [1]. There are also issues related to contextual factor, which include differences on cultural aspects including the belief system, tradition and religion that influence the shaping of an individual's moral structure.[2]. Meanwhile, some researchers have argued on the moral orientations underpinning the dilemma presented in several moral reasoning tests. Nonetheless, these controversial pitfalls have yet to bring the end of utilizing hypothetical dilemma in exploring individuals' moral cognition.

The most common method of conventional morality research, is by making clear distinction between moral cognition, socio-moral, moral empathy, has led to the creation of various schools of thought on moral studies [3]. This isolation, at one point has opened wider opportunities to explore possible components that contribute to the development of humankind moral structure. However, on the other hand, it has limited the views towards gaining better understanding of human thinking ability and this may easily lead to unfair judgment on moral reasoning ability. Moreover, the conventional perspective on moral thinking has established a clear separation on the interaction of emotional and the spiritual dimensions or to be specified as a religious spirituality component in cognitive process. In short, the inclusion of religious spirituality component in human cognitive process is yet to be seen. Therefore there are new interest in moral psychology endeavor currently which taking into account the role of emotional and spiritual components in human reasoning ability [4,5]. For example, in the teaching of most eastern moral psychology (Muslim, Chinese and Indian), there 
is a tendency to give great emphasis in the interrelationship between cognitive, emotion and spiritual components to form human thinking [6]. The Islamic history has shown that human thinking ability has brought the greatest contribution to all human kind. Thus, reasoning does not stand as human perceptual alone. Some psychologists, [7] postulate the possibilities of interconnectedness concerning cognition, emotion and spiritual components in shaping individuals' moral reasoning structure.

\section{Nature and background of moral education for Muslim students in Malaysia}

Morality is deeply rooted in the Malaysian society. In the 'Vision 2020' agenda that was envisioned during the era of Prime Minister Mahathir, morality and ethics are very much emphasized among Malaysians. The Vision 2020, in this respect, was based on the National Education Philosophy, which aims to create Malaysian citizens who are intellectually, spiritually, emotionally, and physically balanced and harmonious, driven by a firm religious belief in God. Moral Education was then introduced as one of the subjects to be taught in the Malaysian school system. [7].

Nonetheless, the Moral Education subject has not been made compulsory for Malay students, who are Muslim. Muslim students are required to enroll for the Islamic Religious subject in schools. The goal of the Islamic Religious subject is to enable the Muslims to understand and practice the concept of Islam as a way of life. In addition, the subject also targets to develop national unity among the multiracial population in Malaysia. The curriculum for the subject has been specifically designed based on the Tawhid (Oneness of God) principle. As part of the curriculum that focuses on integrated and holistic approaches towards individual development and society, another Islamic concept is referred to in shaping and completing the curriculum. This concept is fard-'ain, which basically refers to the individual responsibility towards his/her own faith. Fard- ain intends to promote education as a life-long process among the Muslim. It contains the subject areas that promote development of moral excellence, development of practical skills, and expansion of vocational education to a balanced development of the individual[7]. The teaching of Islamic education in schools has been reported not to focus upon the practical and the internalization aspects of moral virtues but to give more emphasis on the dissemination of information and knowledge about Islam to allow students to perform well in examinations[8].
Furthermore, the present assessment of Religious Education in secondary schools is not specifically focusing on assessing student's internalization and practices of the philosophy of Islamic way of life in more holistic manner [9]. The existing assessment practices that employing paper pencil test has limited contribution concerning IQ, EQ and SQ elements nurtured in Religious Education. In fact, a valid and reliable instrument to help the Religious Education Teachers in carrying out the task is not available.[10]

\section{IQ, EQ and SQ components in the construction of Akhlak Scheme Defining Test (ASDT)}

Based on the combination of Islamic psychology and cognitive schema theory approaches[11]), ASDT was developed with the aim of assessing the moral structure of Malay Muslim students. The ASDT is a compilation of five hypothetical moral dilemmas that represent the moral reasoning structure in a Malay community cultural context. The first dilemma emphasizes moral structure, which is embedded within the Malay family and corresponds to mother-child relationship. The English version of the dilemma is the following.

\begin{abstract}
"Madam Arfah lives with his beloved son, Dali. Dali is a successful businessman and always busy with his chores. Dali always left his mother and wife behind when he travels for his business works. He and his wife always fight because of this matter because his wife can't go along with Madam Arfah. In addition, Madam Arfah is wheelchair bound. Although they have a maid to help, Dali is the one who needs to accompany of his mother the most because Dali's siblings do not have enough money support to take care of her. Hence, all of Dali's siblings decided, Dali is the one who needs to take care of their mother. The conflict between Dali and his wife has forced Dali to consider sending his mother to old folk's home. The care centre that he chose has full accommodation and facilities including nurse and nanny that can take care of his mother. Dali thought that his mother's life can be better and she also can meet new friends of her age in the care center. This will surely give happiness to Madam Arfah, he guessed. Dali brought her mother to the care center with hoping that her mother will agree with his suggestion. In spite of that, Madam Arfah actually felt quite uneasy to be sent to the care center."
\end{abstract}

This is followed by a dilemma revolves around a conflict of students' right versus obedience toward higher authority in the organization. The third dilemma concentrates on moral structure that is related to an issue aroused in multiethnic community. Individual values and collective values are challenged to reach the highest state of being tolerant regardless of races, ethnicity and religion. Meanwhile, the fourth 
dilemma focuses on judgment flanked by flexibility of being friendly and thoughtful among neighborhoods concerning environmental issues. The final dilemma valves contradict emotions on projecting individuals' value revolving in a conflict sandwiched between intimate relation and professional ethics. Each dilemma is accompanied by fourteen items that require the respondent to rate the importance in resolving the dilemma. Subjects are asked to give responses in a Likert scale of one to five arranging from "very most important" to "the least not important". Twelve items were constructed which correspond to the four types of moral reasoning schemas forwarded by Aswati Hamzah[11]. Each schema instills IQ, EQ and SQ as shown in Figure 1.

The operational definition of IQ component in ASDT conjures specific meaning of having the ability to make judgment based on the concept of right and wrong on particular actions and events. Individuals' dispositions towards this component demonstrate their choices of judgment, driven from two ultimate dimensions of Malay individual life that is relationship to GOD and relationship within the interaction with non-human as well as the environment. Preferred values and norms are in accordance with the Islamic teaching of good and bad virtues. Meanwhile, EQ component refers to individuals' inner voices in projecting their emotions, taking into account the good and bad feelings towards particular situations. SQ component, operational definition on the other hand, fabricated spirituality from the theological perspective, includes both the religious and the philosophical aspects of life [12]. SQ component that were incorporated in the hypothetical dilemma is considered as cognitive schemata resulted from the interrelation process of mind, heart and qalb. It represents the underlying process of the development of tawhid (oneness to God concept) worldview amongst the Muslims. It represents the state of acceptance and inclination towards internalization of tawhid concept in one's life.

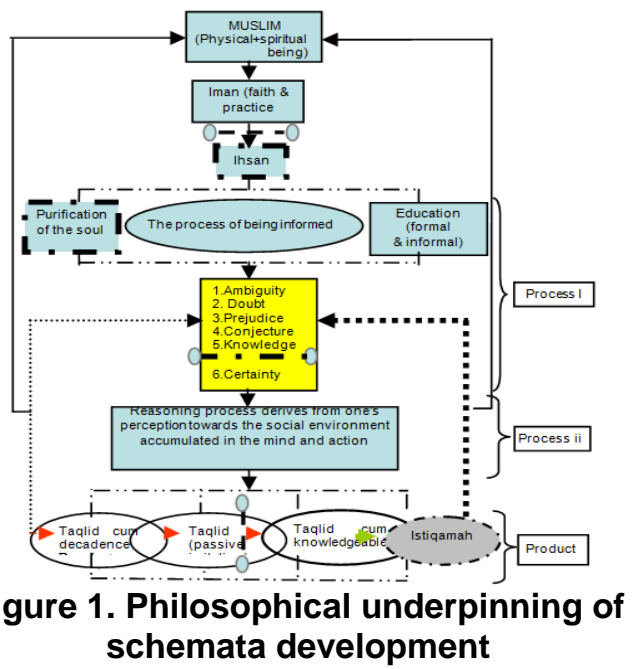

Figure 1 shows the process involves integration of IQ, EQ and SQ components which are intertwined in the search of moral meaning in one's life. The first three boxes containing faith and practices, Ihsan (highest virtues) and purification of the soul manifest the main SQ component. The purification of the soul process required strong and endless spiritual struggles. The yellow boxes, mainly representing the IQ component, which involves the process of knowing in hierarchal order from the lowest level ambiguity to the highest-level certainty. Individual is required to have both components of IQ and SQ to reach the certainty level. Process 1 and process 2 involve induction reasoning determined by the level of knowledge acquired by individual. EQ component occurs closely in between IQ and SQ components to form four different types of schemata. Either EQ emerged in positive form or negative form will work in both directions, coercing individual to move towards good judgment or bad judgment. Thus, EQ component determines an individual's judgment, in which it moves in a continuum of good or bad at each of the two ends.

\section{Method}

This research in particular was carried out as an exploratory research combining quantitative and qualitative methods of data collections. It is a pioneer work in exploring Malay students' moral reasoning schemata which utilized the hypothetical dilemma in the ASDT, adopted from the Defining Issue Test [13]. The following are examples of item for each dilemma.

Dilemma 1-Mother child relationship

\begin{tabular}{|c|l|c|}
\hline $\begin{array}{c}\text { Item } \\
2\end{array}$ & $\begin{array}{l}\text { As long as his mother's life has been } \\
\text { well taken care of, then it is not wrong } \\
\text { for Dali to send his mother to the care } \\
\text { center. }\end{array}$ & \\
\hline $\begin{array}{c}\text { Item } \\
3\end{array}$ & $\begin{array}{l}\text { The feeling and the needs of Dali's } \\
\text { wife should be considered equally } \\
\text { regarding this matter }\end{array}$ & EQ \\
\hline $\begin{array}{c}\text { Item } \\
4\end{array}$ & $\begin{array}{l}\text { The joy of his mother means Dali's } \\
\text { happiness too }\end{array}$ & SQ \\
\hline
\end{tabular}

$\underline{\text { Dilemma 2- Students' right }}$

\begin{tabular}{|c|l|c|}
\hline Item 3 & $\begin{array}{l}\text { The right to voice out among students } \\
\text { is the same with other people's right to } \\
\text { voice out. }\end{array}$ & SQ \\
\hline Item 4 & $\begin{array}{l}\text { Stopping the publication without open } \\
\text { discussion with all sides is considered } \\
\text { not fair }\end{array}$ & EQ \\
\hline Item 5 & $\begin{array}{l}\text { Principal has the right to use his } \\
\text { authority to stop the publication }\end{array}$ & IQ \\
\hline
\end{tabular}




\section{Dilemma 3 - Multiethnic issues}

\begin{tabular}{|c|l|c|}
\hline Item 5 & $\begin{array}{l}\text { Mr. Awang should believe that his } \\
\text { business does not depend on the race } \\
\text { of his mechanic }\end{array}$ & SQ \\
\hline Item 6 & $\begin{array}{l}\text { Hiring Mr Lee means an appreciation } \\
\text { to the talented and skillful person like } \\
\text { him }\end{array}$ & IQ \\
\hline Item 7 & $\begin{array}{l}\text { Mr. Lee may think Mr. Awang as a } \\
\text { racist }\end{array}$ & EQ \\
\hline
\end{tabular}

Dilemma 4- Neighbors

\begin{tabular}{|c|l|c|}
\hline Item 7 & $\begin{array}{l}\text { The neighbors' house cleanliness is } \\
\text { not our responsibility }\end{array}$ & IQ \\
\hline Item 9 & $\begin{array}{l}\text { There are no certain walls that inhibit } \\
\text { us to maintain cleanliness and to be } \\
\text { environmentally friendly }\end{array}$ & SQ \\
\hline Item & $\begin{array}{l}\text { Kamal's wife and children have the } \\
\text { rights to show silent objection } \\
\text { towards Ali and his family }\end{array}$ & EQ \\
\hline
\end{tabular}

Dilemma 5 - Professionalism versus personal relation

\begin{tabular}{|c|l|c|}
\hline Item 2 & $\begin{array}{l}\text { There are things in peoples' life that } \\
\text { are beyond their control }\end{array}$ & SQ \\
\hline Item 4 & $\begin{array}{l}\text { We do not need to take good care of } \\
\text { AIDS patient because eventually they } \\
\text { will still going to die }\end{array}$ & IQ \\
\hline Item 5 & $\begin{array}{l}\text { Moin deserves to gwt the disease due } \\
\text { to his lifestyle }\end{array}$ & EQ \\
\hline
\end{tabular}

Data were gathered from two different groups of students, i.e. students from a public university $(\mathrm{N}=336)$ with the age range of $20-45$ years old, and 16-year-old secondary school students $(\mathrm{N}=$ 396). The findings revealed that four different types of moral structure developed among the Malay students while moral reasoning processes took place in their minds.

\section{Analysis on quantitative and qualitative findings}

Findings from quantitative and qualitative data supported the emergence of IQ, EQ and SQ components embedded in four different types of moral structures. The result from factor analysis procedure indicates four types of reasoning schemas: (1) Istiqamah schemes, (2) Taqlid cum knowledgeable, (3) taqlid, and (4) taqlid cum decadent. The value of KMO (Kaiser-MeyerOlkin Measure of Sampling Adequacy) was .843 and this implies that the sample of this research was statistically appropriate to the test item requirement. Bartlett test also indicate the significance level of 0.000 showing the suitability of the correlation matrix to conduct factor analysis. The reliability index (Cronbach $\alpha$ ) for each schema was as the followings: Istiqamah schema $(\alpha=0.76)$, knowledgeable cum taqlid schema $(\alpha=0.72)$, taqlid schema $(\alpha=0.60)$ and taqlid cum decadence schema

$(\alpha=0.76)$.

Detailed analysis towards Islamic resources (al-Quran and sunnah) and literature work of Islamic scholars were first given emphasis in theorizing the Malay Muslim schemata attributes. Results of factor analysis and individual interview have confirmed the fine points of each schema. Istiqamah schema was the highest in the hierarchy; literally, istiqamah means consistent or sustainable commitment in the way of doing things. In this test, it refers to a state of a clear mind, demonstrates a good consistent relationship in two dimensions towards God and other human beings, as well as God's other creations. This schema would demonstrate one's knowledge, accomplishment, conviction towards the highest virtue as a whole and ability to make others accept the good virtues. This attribute embraces a well blended of IQ, EQ and SQ components in one's moral structure.

Knowledge cum taqlid (imitation, follower) schema, literally means vast knowledge. For the test context, it conjures up meaning of having competencies in acquiring and applying knowledge. It is a demonstration of higher order thinking skills; a projection of scientific and cultural reflective knowledge in reasoning, which covers diverse issues that demand highest degree of values and norms. However, it has a lesser degree of certainty in the connection of two basic principles, which clearly exists in istiqamah schemes. Taqlid element is identified in this schema which notably associated to the influenced of EQ component on making judgment. Following knowledge cum taqlid schema is the Taqlid schema. Literally, it means passive imitation. It conjures up an attribute of the following without knowing, i.e. follows the norms and custom or adat without particular knowledge. This reasoning scheme in particular shows less degree of knowledge and high inclination of activating EQ components while making judgment. Decadent schema, on the other hand, literally comes from the word decay. It refers to the phenomena of declining in norms or value. The most prominent character of this schema is more appealing towards EQ components.

The overall distributions of students for each category of schema are as follows.

Table 1. Number of student for each schema category

\begin{tabular}{|l|l|}
\hline Categony & Percent \\
\hline Istiqamalh & 46.3 \\
\hline $\begin{array}{l}\text { Knowledgeable cum taqlid (With follower } \\
\text { attitudes) }\end{array}$ & 9.4 \\
\hline Taqlid (Follower, imitating) & 14.2 \\
\hline Taqlid cum decadence & 14.5 \\
\hline Total & 84.4 \\
\hline Not belonging to any Schema category & 15.6 \\
\hline Overall total & 100.0 \\
\hline
\end{tabular}


Table 1 shows almost half of the students articulated istiqamah characteristic on their moral reasoning. Meanwhile students were distributed quite equally for the three lower schemas. Surprisingly, result also shows that there was $15.6 \%$ of students formed a group of unidentified schema.

Further analysis on the form of schemas reveals the emergence of additive layer- cake form attributes of mixture of the schemas. In line with this, Islamic psychology view of individual inclination and willingness to sustain their struggle to achieve the highest virtues was taken into consideration. Individuals are believed to exhibit strong inclination towards particular virtues. In accordance with this fact, their physical and spiritual responses could be in the degree of complete conviction, being knowledgeable, imitating or declining from accepted norms. Hence, the formulation of schema category shows a phenomena of mixture responses represent the heart - mind - qalb state reflected Malay individual reason, emotion, rationality and budi. For example, Istiqamah category was formed as a result of summation in a ratio of $75 \%$ score of istiqamah construct, $10 \%$ complement schema (knowledgeable cum taqlid schema) and 10\% complement of taqlid schema and 5\% of taqlid cum decadent schema.

\section{Insight: Impact and direction for future use of hypothetical dilemma to promote moral development}

Studies on the Muslim students' moral development and reasoning ability, specifically in Malaysian context, are limited for the time being. Results from this study in particular exhibit more possibilities of employing hypothetical dilemma as techniques or tools to promote positive moral development, interactive pedagogy to stimulate moral virtue among Muslim students. Previous research on Islamic education in Malaysia indicates that Malay Muslim students lack the ability to practice high level of critical thinking skills[14,15]. It was also found that the students are incapable of making the right or appropriate assessments of situations that put them in conflict, especially when it concerns the tension caused by the collision between eastern and western values or norms.[7] It is also reported that they have a low level of critical thinking ability in considering norms and values. Apparently, the strongest point of ASDT as pedagogical tools would be able to assist students to articulate Muslim moral values and promote critical moral thinking skills while surrounded by the Malay community.

From the analysis of statistical and nonstatistical data, the moral constructs and moral development of Muslim students' had been empirically illustrated. The continuation of taqlid elements and a group of students that excluded from the four-schema group suggest a missing structure or potential construct which are worth to be further explored in future research. Despite several findings discussed above, the results also captured the existence of filters in schema formation, that is particular values and elements held by individuals while making judgments. Muslim students held on their beliefs on adat (norms) and budaya (tradition) Malay's traditional life that stem from Islamic teaching on making moral judgment. In other words, the element of norm and tradition of Malay people should be included in constructing hypothetical dilemma among Malaysian Muslims.

In addition, hypothetical dilemmas in ASDT were found to have pedagogical impact on moral and religious teaching. Hypothetical dilemma could be introduced as a main component of interactive pedagogy on moral and religious subject in school. Result of the studies indicated the process of teaching and learning had unwittingly left out the aspects of nurturing the elements of 'purifying the soul' albeit it was the crucial ability level to drive individual students to reach the highest rank in knowledge hierarchical order. Students' responses towards ASDT items exhibit the role of emotion on students' reasoning. This aspect while important is not focused in the existing teaching and learning process of moral and religious subject. Finally, results also reveal that religion influenced the students' moral competencies in making good judgment. It exists as a dominant value system affecting student inclination towards best practices virtues of Malay moral standards, which furthermore plays a significant role in shaping their morality. Therefore, religious spirituality is empirically tested to stand as a prominent component in Malay moral structure.

Besides, the established version of ASDT could be useful to assess students' moral competencies to attain better explanation of their moral structure. To date, not much empirical data and scientific resources documented on the morality of the Malay Muslim students. Furthermore, the existing evaluation system does not provide the right tools to promote students' reasoning skills. Hence, it is necessary to identify and comprehend the Malay students' moral mind and moral competencies attributes.

\section{Conclusion}

Developing and utilizing hypothetical dilemma for Malay Muslim students should remark the philosophical framework suggested by distinguished Malaysian Muslim Scholar [16] 
stressing morality as 'the rules of one's self by itself since the trust of responsibility and freedom of the self to do justice to itself". Accordingly manifesting an interconnectedness of IQ, EQ and SQ components of Malay moral virtues.

\section{References}

[1] Teper, R (2009). Do Moral Action and moral prediction go hand in hand? Exploring Morality as a function of Self Regulation. Master Thesis, Department of Psychology, University of Toronto, retrieve from https://tspace.library.utoronto.ca/bitstream/1807/18963/ 1/Teper_Rimma_200911_MA_thesis.pdf (Access date: 14 February, 2011).

[2] Gielen, U.P. \& Markoulis, D.C. (1994) Preference for principal moral reasoning: A developmental and cross-cultural perspectives. In L.L. Adler \& U.P. Gielen (eds) Cross-cultural topics in psychology (pp. 73-87). Westport, CT : Greenwood.

[3] Kurtinez W,M and Gewirtz, L, J (1991) Handbook of Moral Behaviour \& Development Volume :1:Theory. Lawrence Earlbaum Associates: New Jersey.

[4] Walker, L. J. (2003) Morality, Religion, Spirituality- the value of saintliness. Journal of Moral Education, 2003 Vol 32, Issue 4.pg 373.

[5] Walker,L.J.\& Reimer, K.S. (2006). The relationship between moral and spiritual development. In E.C. Roehlkepartain, P.E. King, L. Wagener, \& P.L. Benson (Eds), The handbook of spiritual development in childhood and adolescence (pp 224-238) Thousand Oaks, CA: Sage

[6] Green, M,R (1988) Religion and Moral Reason: A new Method for Comparative Study. Oxford University Press : Oxford.

[7] Aswati Hamzah and Khadijah Zon (2010). Identification and Characterization of Malay student's Moral Reasoning competencies in "Educating competences for democracy" First Volume, Eds.:Dawn Schrader (Cornell Univ. Ithaca, NY), Ewa Nowak (Poznan Univ., Poland), Peter Lang Verlag, Series DiaLogos, 2010.(In process)

[8] Aswati Hamzah, Khadijah Zon and Sharifah Norhaidah Syed Idros (2008). Responses to Globalization in Malaysian Islamic Education: Philosophical-Underpinnings, Curricular Changes, Revivalism and the Moderate Islam Hadhari. Paper presented at the 8th Annual Conference of the Iranian Curriculum Studies Association (ICSA). The university of Mazandaran, Iran.

[9] Zainal Abidin Hj Abdul Kadir (1998) Islamic Internalization of Secondary School New Curriculum: Method and Implementation. Paper presented at Seminar on upgrading Integrated Education at Islamic Teaching College. Kuala Lumpur August 31998.
[10] Aswati Hamzah and Mohd Zailani Mohd Yusoff (2008). The Development of Islamic Spiritual Disposition Questionnaire: Conference On Malaysian Study Of Islam, University of Wales, Lampeter,United Kingdom. 28-29 June 2008.

[11] Aswati Hamzah (2006). Philosophical Underpinning of constructing Akhlak Reasoning Scheme Scale. Paper presented at the $3^{\text {rd }}$ International Conference on Measurement : and Evaluation in Education (ICMEE), Park Royal Hotel, Penang. 13-15 February 2006.

[12] Schneiders, S M (1986), Theology and spirituality: Strangers, rivals or partners? Horizons, 13. 253-274.

[13] Rest, J. Thoma,S. Narvaez, D. Bebeau. (1999) DIT2: Devising and Testing a Revised Instrument of Moral Judgment. Journal of Educational Psychology 1999, Vol. 91, no 4, 644-659.

[14] Abdul Kadir Ariffin (2003),. The Effect of Islamic Internalization and Experiential Approaches Towards Form 2 Students' Higher Level Thinking. Unpublished Doctoral Dissertation. University Sains Malaysia, Penang.

[15] Aswati Hamzah ( 2007) A Study of Akhlak Reasoning Schemes Among Malay Students Unpublished Doctoral Dissertation, University Sains Malaysia, Penang, Malaysia.

[16] Al-Attas,S.M (1990) The nature of man and The Psychology of the Human Soul. A Brief Outline and Framework for an Islamic Psychology and Epistemology. Kuala Lumpur: International Institute of Islamic Thought and Civilization. 